\title{
Keragaan dan Kemampuan Meratun Lima Genotipe Sorgum
}

\section{Performance and Ratooning Ability of Five Sorghum Genotypes}

\author{
Merry Gloria Meliala1 ${ }^{1}$, Trikoesoemaningtyas ${ }^{2}$, dan Didy Sopandie ${ }^{2 *}$ \\ ${ }^{1}$ Program Studi Agronomi dan Hortikultura, Sekolah Pascasarjana, Institut Pertanian Bogor \\ ${ }^{2}$ Departemen Agronomi dan Hortikultura, Fakultas Pertanian, Institut Pertanian Bogor \\ (Bogor Agricultural University), Jl. Meranti, Kampus IPB Darmaga, Bogor 16680, Indonesia
}

Diterima 21 Juni 2016/Disetujui 17 November 2016

\begin{abstract}
Ratooning can be used as an alternative cultivation technique for production of sorghum. This study was aimed to evaluate the growth and production of ratoon following the main crop. The study was conducted during August 2013 until November 2014, at Cikabayan Experimental Station, Bogor Agricultural University. The research was arranged in a randomized complete block design with four replications. The results showed that genotypes was significantly affected the vegetative and reproductive characters, physiologycal characters of the main crop, ratooning ability, and vegetative characters of ratoon crop. Plant height, stem diameter, fresh and dry weight, harvest time, and harvest index of main crops had significant correlation with ratooning ability. Plant height, total chlorophyll, fresh and dry weight, panicle weight, grain weight per panicle, 1,000 grain weight, harvest index, and transpiration rate of main crops had significant correlation with ratoon growth. Based on path analysis, the main crop growth directly affected ratoon height, and vegetative characters of ratoon directly affected the yield. The ratoon yielded $48.9-65.7 \%$ of the main crop yield.
\end{abstract}

Keywords: path analysis, ratooning ability, ratoon crops

\section{ABSTRAK}

Salah satu teknik budidaya yang dapat digunakan dalam pengembangan sorgum adalah ratun. Penelitian bertujuan untuk mengevaluasi pengaruh pertumbuhan dan produksi tanaman utama lima genotipe sorgum terhadap pertumbuhan dan produksi tanaman ratun. Penelitian dilaksanakan pada Agustus 2013 - November 2014 di Kebun Percobaan Cikabayan, Institut Pertanian Bogor. Percobaan dilakukan menggunakan rancangan acak kelompok empat ulangan. Genotipe berpengaruh nyata terhadap karakter vegetatif, reproduktif, fisiologi tanaman utama, kemampuan meratun dan karakter vegetatif tanaman ratun. Karakter tanaman utama yang berkorelasi nyata dengan kemampuan meratun adalah tinggi tanaman, diameter batang, bobot basah dan kering brangkasan, umur panen, dan indeks panen. Karakter tanaman utama yang berkorelasi nyata dengan keragaan tanaman ratun adalah tinggi tanaman utama, total klorofil daun, bobot basah brangkasan, bobot kering brangkasan, bobot malai, bobot biji per malai, bobot 1,000 biji, indeks panen, dan laju transpirasi. Berdasarkan hasil sidik lintas, pertumbuhan tanaman utama mempunyai pengaruh langsung terhadap tinggi ratun, dan vegetatif ratun mempunyai pengaruh langsung terhadap produksi ratun. Produksi ratun mencapai 48.9-65.7\% dari produksi tanaman utama. Masa panen tanaman utama lebih cepat menyebabkan ketersediaan air masih dapat digunakan oleh tanaman ratun. Ketersediaan air ini membuat penerapan ratun sesuai untuk budidaya sorgum lahan kering.

Kata kunci: kemampuan meratun, tanaman ratun, sidik lintas

\section{PENDAHULUAN}

Sorgum dapat digunakan sebagai tanaman sumber pangan, pakan, dan energi. Peningkatan kebutuhan pangan, pakan, dan energi terjadi seiring dengan peningkatan jumlah penduduk Jumlah penduduk Indonesia pada tahun 2015 mencapai 255.18 juta orang (BPS, 2015). Jumlah penduduk

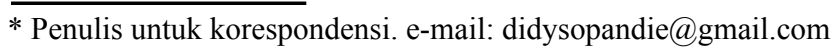

Indonesia diperkirakan akan meningkat menjadi 284.8 juta orang pada tahun 2025 (BPS, 2013).

Sorgum merupakan tanaman yang toleran kekeringan dan suhu tinggi. Efisiensi penggunaan air sorgum lebih tinggi dibandingkan tanaman $\mathrm{C} 4$ lain seperti jagung (Amaducci et al., 2016). Efisiensi penggunaan air menunjukkan rasio antara bobot kering tanaman dengan jumlah air yang digunakan (Cosentino et al., 2012). Efisiensi penggunaan air sorgum sebesar $52 \mathrm{~kg} \mathrm{ha}^{-1} \mathrm{~mm}^{-1}$ sedangkan jagung $38 \mathrm{~kg}$ $\mathrm{ha}^{-1} \mathrm{~mm}^{-1}$ (Amaducci et al., 2016). 
Ratun pada sorgum telah lama mendapat perhatian peneliti karena adanya keuntungan budidaya ratun, yaitu umurnya relatif lebih pendek dibandingkan tanaman utama, kebutuhan air lebih sedikit, dan biaya produksi lebih rendah (Mekbib, 2009; Liu et al., 2016; Puspitasari et al., 2012). Untuk menumbuhkan ratun, batang tanaman musim tanam pertama dipotong, dibiarkan tumbuh kembali dan dibudidayakan seperti sorgum yang ditanam dari benih. Namun penelitian pada keragaan dan kemampuan meratun masih perlu dilakukan dalam rangka memahami basis genetik potensi ratun.

Penelitian tentang ratun sorgum yang telah dilakukan antara lain adalah pengaruh budidaya ratun terhadap hasil, produksi gula, dan serangan hama (Wilson, 2011), evaluasi pertumbuhan dan hasil sorgum manis pada jarak tanam berbeda (Puspitasari et al., 2012), evaluasi genotipe sorgum manis produksi biomas dan daya ratun tinggi (Efendi et al., 2013). Kemampuan menumbuhkan ratun tidak sama untuk setiap genotipe. Genotipe yang berbeda memiliki perbedaan kemampuan meratun pada padi (Balasubramanian et al., 1992) dan tebu (Shah et al., 2008), juga perbedaan hasil ratun pada padi (Akhgari et al., 2013; Sinaga et al., 2015) dan sorgum (Hassan et al., 2015). Produksi ratun ditentukan oleh keragaan tanaman utama (Harrel et al., 2009; Sanni et al., 2009) dan teknik panen (Susilawati et al., 2012). Hasil tanaman utama juga memiliki korelasi nyata dan positif dengan hasil tanaman ratun (Liu et al., 2015). Penelitian ini bertujuan untuk mengevaluasi pengaruh pertumbuhan dan produksi tanaman utama lima genotipe sorgum terhadap kemampuan meratun serta pertumbuhan dan produksi tanaman ratun.

\section{BAHAN DAN METODE}

Penelitian dilaksanakan di kebun percobaan Cikabayan, Laboratorium Pasca Panen, dan Laboratorium Spektrofotometri Departemen Agronomi dan Hortikultura, Fakultas Pertanian, Institut Pertanian Bogor, pada Agustus 2013 sampai November 2014. Bahan tanaman yang digunakan adalah genotipe Kawali, Mandau, N/UP-118-3, Numbu, dan UPCA. Rancangan percobaan yang digunakan adalah Rancangan Acak Kelompok satu faktor yaitu genotipe dengan 4 ulangan. Data dianalisis melalui analisis ragam, uji lanjut DMRT dan analisis korelasi.

Sorgum ditanam dengan jarak tanam $70 \mathrm{~cm}$ x $15 \mathrm{~cm}$. Dosis pupuk yang digunakan adalah $150 \mathrm{~kg} \mathrm{ha}^{-1}$ urea, 100 $\mathrm{kg} \mathrm{ha}^{-1} \mathrm{KCl}$, dan $100 \mathrm{~kg} \mathrm{ha}^{-1} \mathrm{SP}-36$. Tanaman sorgum yang tumbuh dari benih disebut tanaman utama. Setelah panen, sorgum diratun dengan cara melakukan pemotongan batang tanaman utama dan menyisakan satu buku dari permukaan tanah, sekitar 5-10 cm dari tanah. Tanaman yang tumbuh dari buku yang tersisa disebut tanaman ratun. Pemeliharaan tanaman ratun sama dengan tanaman utama. Dosis pupuk tanaman ratun sama dengan dosis pupuk tanaman utama. Pupuk diberikan 3 minggu setelah pemotongan.

Peubah yang diamati pada tanaman utama adalah karakter vegetatif, reproduktif, dan fisiologi. Karakter vegetatif yang diamati terdiri atas tinggi tanaman, jumlah daun, diameter batang, bobot basah dan kering brangkasan bagian atas. Karakter reproduktif yang diamati terdiri atas umur berbunga dan panen, bobot malai, bobot biji per malai, bobot 1,000 biji, dan indeks panen. Karakter Fisiologi yang diamati terdiri atas kehijauan daun diukur menggunakan SPAD-502, kandungan pigmen (klorofil a, klorofil b, antosianin, karoten, dan total klorofil) menggunakan metode analisis Sims dan Gamon (2002), laju fotosintesis, respirasi, transpirasi dan konduktansi stomata diukur menggunakan Licor 6400, serta gula total menggunakan metode Yoshida et al. (1976). Peubah yang diamati pada tanaman ratun adalah karakter vegetatif, karakter reproduktif, dan kemampuan meratun (waktu muncul ratun, jumlah ratun tumbuh, persentase ratun tumbuh).

\section{HASIL DAN PEMBAHASAN}

\section{Pengaruh Genotipe terhadap Keragaan Tanaman Utama}

Penampilan tanaman utama yang baik akan berpengaruh terhadap penampilan tanaman ratun. Genotipe berpengaruh nyata terhadap karakter vegetatif tanaman utama (Tabel 1). Tinggi tanaman, jumlah daun, diameter batang, bobot basah dan kering tanaman dipengaruhi oleh genotipe tanaman.

Genotipe juga berpengaruh nyata terhadap semua karakter reproduktif tanaman (Tabel 2). Umur berbunga, umur panen, bobot malai, bobot biji per malai, bobot 1,000 biji dan indeks panen dipengaruhi oleh genotipe tanaman. Pengaruh genotipe terhadap keragaman karakter vegetatif dan reproduktif menunjukkan bahwa perbedaan nilai pada karakter yang diamati disebabkan oleh perbedaan genotipe. Genotipe berpengaruh nyata terhadap bobot kering padi (Nakano dan Morita, 2007).

\section{Pengaruh Genotipe terhadap Fisiologi Tanaman Utama}

Genotipe berpengaruh nyata terhadap kandungan klorofil b, total klorofil, dan kehijauan daun namun tidak berpengaruh nyata terhadap kandungan klorofil a, antosianin, dan karoten daun (Tabel 3). Genotipe berpengaruh nyata terhadap laju fotosintesis, konduktansi stomata, $\mathrm{CO}_{2}$ interselular, dan laju transpirasi tanaman sorgum (Tabel 4). Xiong et al. (2014) melaporkan bahwa laju transpirasi berkorelasi dengan karbohidrat nonstruktural dan produksi biji. Seperti dilaporkan oleh Saberi dan Aishah (2014) mengenai pengaruh fisiologi terhadap sorgum pakan genotipe Speedfeed dan KFS4. Tanaman ratun sorgum tersebut mempunyai rata-rata laju fotosintesis sebesar 15.61 $\mu \mathrm{mol} \mathrm{m} \mathrm{s}^{-2}$ dan konduktansi stomata sebesar $0.12 \mathrm{mmol} \mathrm{m}^{-}$ ${ }^{2} \mathrm{~S}^{-1}$. Sorgum pada percobaan ini mempunyai laju fotosintesis dan konduktansi stomata yang lebih tinggi dibandingan Speedfeed dan KFS4.

\section{Pengaruh Genotipe terhadap Kemampuan Meratun}

Genotipe berpengaruh nyata terhadap karakter yang menunjukkan kemampuan meratun tanaman yaitu waktu muncul ratun, jumlah dan persentase ratun tumbuh (Tabel 5). Efendi et al. (2013) menyatakan bahwa kemampuan meratun 
Tabel 1. Tinggi, jumlah daun, bobot basah, dan bobot kering tanaman utama lima genotipe sorgum

\begin{tabular}{lccccc}
\hline Genotipe & $\begin{array}{c}\text { Tinggi tanaman } \\
(\mathrm{cm})\end{array}$ & $\begin{array}{c}\text { Jumlah } \\
\text { daun }\end{array}$ & $\begin{array}{c}\text { Diameter batang } \\
(\mathrm{mm})\end{array}$ & $\begin{array}{c}\text { Bobot basah } \\
(\mathrm{g})\end{array}$ & $\begin{array}{c}\text { Bobot kering } \\
(\mathrm{g})\end{array}$ \\
\hline Kawali & $185.28 \mathrm{~d}$ & $10.23 \mathrm{a}$ & $18.09 \mathrm{~b}$ & $241.58 \mathrm{~b}$ & $82.37 \mathrm{c}$ \\
Mandau & $250.21 \mathrm{~b}$ & $10.00 \mathrm{a}$ & $18.22 \mathrm{~b}$ & $400.47 \mathrm{a}$ & $113.69 \mathrm{~b}$ \\
N/UP-118-3 & $234.53 \mathrm{c}$ & $10.02 \mathrm{a}$ & $19.40 \mathrm{a}$ & $403.66 \mathrm{a}$ & $87.31 \mathrm{c}$ \\
Numbu & $270.27 \mathrm{a}$ & $9.97 \mathrm{a}$ & $17.96 \mathrm{~b}$ & $426.52 \mathrm{a}$ & $165.13 \mathrm{a}$ \\
UPCA & $188.85 \mathrm{~d}$ & $7.22 \mathrm{~b}$ & $16.74 \mathrm{c}$ & $193.67 \mathrm{c}$ & $37.96 \mathrm{~d}$ \\
\hline Rata-rata & 226.44 & 9.4 & 18.08 & 327.16 & 95.98 \\
\hline
\end{tabular}

Keterangan: Angka pada kolom sama yang diikuti huruf berbeda, berbeda nyata pada $\alpha 5 \%$

Tabel 2. Umur berbunga, umur panen, bobot malai, bobot biji per malai, bobot 1,000 biji dan indeks panen tanaman utama lima genotipe sorgum

\begin{tabular}{lcccccc}
\hline Genotipe & $\begin{array}{c}\text { Umur Bebunga } \\
\text { (hari) }\end{array}$ & $\begin{array}{c}\text { Umur Panen } \\
(\text { hari })\end{array}$ & $\begin{array}{c}\text { Bobot malai } \\
(\mathrm{g})\end{array}$ & $\begin{array}{c}\text { Bobot biji } \\
\text { per malai }(\mathrm{g})\end{array}$ & $\begin{array}{c}\text { Bobot 1,000 } \\
\text { biji }(\mathrm{g})\end{array}$ & $\begin{array}{c}\text { Indeks } \\
\text { Panen }\end{array}$ \\
\hline Kawali & $84.25 \mathrm{~b}$ & $115.50 \mathrm{~b}$ & $38.78 \mathrm{c}$ & $21.07 \mathrm{c}$ & $12.29 \mathrm{~d}$ & $0.32 \mathrm{c}$ \\
Mandau & $91.25 \mathrm{a}$ & $122.50 \mathrm{a}$ & $19.35 \mathrm{~d}$ & $14.26 \mathrm{~d}$ & $17.16 \mathrm{c}$ & $0.14 \mathrm{~d}$ \\
N/UP-118-3 & $87.25 \mathrm{~b}$ & $114.75 \mathrm{~b}$ & $46.92 \mathrm{~b}$ & $28.99 \mathrm{~b}$ & $12.66 \mathrm{~d}$ & $0.36 \mathrm{~b}$ \\
Numbu & $84.50 \mathrm{~b}$ & $118.00 \mathrm{~b}$ & $80.23 \mathrm{a}$ & $62.86 \mathrm{a}$ & $28.50 \mathrm{a}$ & $0.32 \mathrm{c}$ \\
UPCA & $79.25 \mathrm{c}$ & $108.75 \mathrm{c}$ & $41.09 \mathrm{bc}$ & $32.28 \mathrm{~b}$ & $19.66 \mathrm{bb}$ & $0.51 \mathrm{a}$ \\
\hline Rata-rata & 85.30 & 115.90 & 47.93 & 33.92 & 18.02 & 0.33 \\
\hline
\end{tabular}

Keterangan: Angka pada kolom sama yang diikuti huruf berbeda, berbeda nyata pada $\alpha 5 \%$

Tabel 3. Kandungan klorofil dan kehijauan daun tanaman utama lima genotipe sorgum

\begin{tabular}{lcccccc}
\hline Genotipe & $\begin{array}{c}\text { Klorofil a } \\
\left(\mathrm{mg} \mathrm{g}^{-1}\right)\end{array}$ & $\begin{array}{c}\text { Klorofil b } \\
\left(\mathrm{mg} \mathrm{g}^{-1}\right)\end{array}$ & $\begin{array}{c}\text { Total klorofil } \\
\left(\mathrm{mg} \mathrm{g}^{-1}\right)\end{array}$ & $\begin{array}{c}\text { Antosianin } \\
\left(\mu \mathrm{mol} \mathrm{g}^{-1}\right)\end{array}$ & $\begin{array}{c}\text { Karoten } \\
\left(\mathrm{mg} \mathrm{g}^{-1}\right)\end{array}$ & $\begin{array}{c}\text { Kehijauan } \\
\text { Kawali }\end{array}$ \\
2.47 & $0.85 \mathrm{ab}$ & $3.32 \mathrm{ab}$ & 0.52 & 0.51 & $49.63 \mathrm{a}$ \\
Mandau & 2.27 & $0.74 \mathrm{c}$ & $2.97 \mathrm{~b}$ & 0.47 & 0.72 & $45.24 \mathrm{~b}$ \\
N/UP-118-3 & 2.34 & $0.76 \mathrm{bc}$ & $3.10 \mathrm{~b}$ & 0.46 & 0.71 & $46.40 \mathrm{~b}$ \\
Numbu & 2.61 & $0.87 \mathrm{a}$ & $3.49 \mathrm{a}$ & 0.53 & 0.53 & $48.43 \mathrm{a}$ \\
UPCA & 2.47 & $0.80 \mathrm{abc}$ & $3.27 \mathrm{ab}$ & 0.51 & 0.51 & $49.55 \mathrm{a}$ \\
\hline Rata-rata & 2.45 & 0.81 & 3.24 & 0.34 & 0.50 & 47.85 \\
\hline
\end{tabular}

Keterangan: Angka pada kolom sama yang diikuti huruf berbeda, berbeda nyata pada $\alpha 5 \%$

Tabel 4. Laju fotosintesis, konduktansi stomata, $\mathrm{CO}_{2}$ interselular, dan laju transpirasi tanaman utama lima genotipe sorgum

\begin{tabular}{lcccc}
\hline Genotipe & $\begin{array}{c}\text { Laju fotosintesis } \\
\left(\mu \mathrm{mol} \mathrm{CO} \mathrm{m}^{-2} \mathrm{~s}^{-1}\right)\end{array}$ & $\begin{array}{c}\text { Konduktasi stomata } \\
\left(\mathrm{mol} \mathrm{H}_{2} \mathrm{O} \mathrm{m}^{-2} \mathrm{~s}^{-1}\right)\end{array}$ & $\begin{array}{c}\mathrm{CO}_{2} \text { Interselular } \\
\left(\mu \mathrm{mol} \mathrm{CO}_{2} \mathrm{~mol} \mathrm{udara}^{-1}\right)\end{array}$ & $\begin{array}{c}\text { Laju transpirasi } \\
\left(\mathrm{mol} \mathrm{H}_{2} \mathrm{O} \mathrm{m}^{-2} \mathrm{~s}^{-1}\right)\end{array}$ \\
\hline Kawali & $26.67 \mathrm{~d}$ & $0.23 \mathrm{c}$ & $173.9 \mathrm{~b}$ & $3.54 \mathrm{c}$ \\
Mandau & $28.67 \mathrm{c}$ & $0.25 \mathrm{c}$ & $154.83 \mathrm{~b}$ & $3.94 \mathrm{~b}$ \\
N/UP-118-3 & $30.63 \mathrm{ab}$ & $0.28 \mathrm{c}$ & $167.85 \mathrm{~b}$ & $4.00 \mathrm{~b}$ \\
Numbu & $31.45 \mathrm{a}$ & $0.32 \mathrm{~b}$ & $204.55 \mathrm{a}$ & $4.14 \mathrm{~b}$ \\
UPCA & $29.31 \mathrm{bc}$ & $0.37 \mathrm{a}$ & $208.53 \mathrm{a}$ & $4.65 \mathrm{a}$ \\
\hline Rata-rata & 29.22 & 0.29 & 180.97 & 4.05 \\
\hline
\end{tabular}

Keterangan: Angka pada kolom sama yang diikuti huruf berbeda, berbeda nyata pada $\alpha 5 \%$ 
dipengaruhi oleh genetik. Waktu muncul ratun tanaman sorgum lebih lama dari padi. Waktu muncul ratun adalah waktu keluarnya tunas ratun dan menghasilkan beberapa anakan. Susilawati et al. (2012) menyatakan bahwa tunas ratun pada padi muncul pada hari kedua sampai keempat setelah panen. Rata-rata waktu muncul ratun sorgum adalah 8.8 hari setelah panen (Tabel 5).

Rata-rata ratun tumbuh sebesar 8.7 tanaman dengan persentase sebesar 30.83\% (Tabel 5). Persentase ratun tumbuh sorgum pada percobaan ini lebih rendah dibandingkan persentase ratun tumbuh sorgum manis yang dipanen batangnya yaitu sebesar 69.3\% (Efendi et al., 2013). Efendi et al. (2013) melaporkan bahwa secara umum dari 14 genotipe yang diuji pada penelitian tersebut, tanaman utama yang memiliki kadar gula lebih tinggi akan menghasilkan persentase ratun lebih tinggi.

\section{Pengaruh Genotipe terhadap Keragaan Tanaman Ratun}

Genotipe berpengaruh nyata terhadap semua karakter vegetatif tanaman ratun (Tabel 5). Tinggi tanaman, jumlah daun, dan diameter batang tanaman ratun dipengaruhi oleh genotipe tanaman. Pertumbuhan dan perkembangan ratun padi dipengaruhi oleh pertumbuhan tanaman utama (Liu et al., 2012). Semua karakter vegetatif tanaman ratun mengalami penurunan nilai bila dibandingkan tanaman utama. Tanaman ratun lebih pendek, jumlah daun lebih sedikit, dan diameter batang lebih kecil dibandingkan tanaman utama walaupun dipupuk dengan dosis yang sama dengan tanaman utama. Penurunan nilai karakter vegetatif tanaman ratun dibandingkan tanaman utama juga terjadi pada ratun padi (Balasubramanian et al., 1992; Sinaga, 2015) dan tebu (Gomathi et al., 2013).

Umur panen tanaman ratun lebih cepat dibandingkan tanaman utama (Tabel 6). Mandau, Numbu, dan UPCA dipanen 7, 19 dan 18 hari lebih cepat dibandingkan tanaman utama. Susilawati et al. (2012) menyatakan bahwa tanaman ratun padi dipanen lebih cepat 49-62 hari dibandingkan tanaman utama, umur panen tanaman ratun padi yang lebih pendek disebabkan ratun memiliki fase pertumbuhan yang berbeda dengan tanaman utama. Tanaman utama padi memiliki tiga fase pertumbuhan yaitu fase vegetatif, reproduktif dan pemasakan sedangkan tanaman ratun hanya memiliki dua fase yaitu reproduktif dan pemasakan. Berbeda dengan padi, ratun sorgum memiliki fase yang sama dengan fase tanaman utamanya.

Tanaman ratun genotipe Numbu mempunyai nilai karakter reproduktif yang lebih tinggi dibandingkan Mandau dan UPCA. Bobot malai, bobot biji per malai, bobot 1,000 biji, dan indeks panen genotipe Numbu lebih tinggi dibandingkan Mandau dan UPCA (Tabel 6). Bobot malai, bobot biji/malai, dan bobot 1,000 biji mengalami penurunan dibandingkan tanaman utama. Produksi Mandau, Numbu, dan UPCA dibandingkan tanaman utama berturut-turut adalah 48.94\%, 65.73\%, dan 48.94\%. Tanaman ratun N/UP118-3 dan Kawali tidak menghasilkan produksi. Produksi ratun padi dibandingkan tanaman utama bervariasi antara 0-91\% (Sinaga, 2015). Ratun tanaman tebu juga mengalami penurunan hasil dibandingkan tanaman utama (Viator et al., 2010).

Tabel 5. Kemampuan meratun dan karakter vegetatif tanaman ratun lima genotipe sorgum

\begin{tabular}{lcccccc}
\hline Genotipe & $\begin{array}{c}\text { Waktu muncul } \\
\text { ratun (hari) }\end{array}$ & $\begin{array}{c}\text { Jumlah ratun } \\
\text { tumbuh }\end{array}$ & $\begin{array}{c}\text { Persentase ratun } \\
\text { tumbuh }(\%)\end{array}$ & $\begin{array}{c}\text { Tinggi tanaman } \\
(\mathrm{cm})\end{array}$ & $\begin{array}{c}\text { Jumlah } \\
\text { daun }\end{array}$ & $\begin{array}{c}\text { Diameter } \\
\text { batang }(\mathrm{mm})\end{array}$ \\
\hline Kawali & $9.50 \mathrm{a}$ & $5.50 \mathrm{bc}$ & $18.67 \mathrm{bc}$ & $158.00 \mathrm{~b}$ & $9.33 \mathrm{~b}$ & $13.75 \mathrm{ab}$ \\
Mandau & $9.75 \mathrm{a}$ & $12.75 \mathrm{a}$ & $43.60 \mathrm{a}$ & $175.31 \mathrm{~b}$ & $9.15 \mathrm{~b}$ & $11.60 \mathrm{~b}$ \\
N/UP-118-3 & $7.25 \mathrm{~b}$ & $3.25 \mathrm{c}$ & $11.27 \mathrm{c}$ & $182.31 \mathrm{~b}$ & $9.28 \mathrm{~b}$ & $14.21 \mathrm{a}$ \\
Numbu & $9.50 \mathrm{a}$ & $12.75 \mathrm{a}$ & $48.09 \mathrm{a}$ & $225.39 \mathrm{a}$ & $11.22 \mathrm{a}$ & $14.66 \mathrm{a}$ \\
UPCA & $8.00 \mathrm{ab}$ & $9.25 \mathrm{ab}$ & $32.56 \mathrm{ab}$ & $166.39 \mathrm{~b}$ & $9.26 \mathrm{~b}$ & $12.75 \mathrm{ab}$ \\
\hline Rata-rata & 8.80 & 8.70 & 30.83 & 188.97 & 9.87 & 13.29 \\
\hline
\end{tabular}

Keterangan: Angka pada kolom sama yang diikuti huruf berbeda, berbeda nyata pada $\alpha 5 \%$

Tabel 6. Karakter reproduktif tanaman ratun lima genotipe sorgum

\begin{tabular}{lcccccc}
\hline Genotipe & $\begin{array}{c}\text { Umur panen } \\
\text { (hari) }\end{array}$ & $\begin{array}{c}\text { Bobot malai } \\
(\mathrm{g})\end{array}$ & $\begin{array}{c}\text { Bobot biji per } \\
\text { malai }(\mathrm{g})\end{array}$ & $\begin{array}{c}\text { Bobot 1,000 } \\
\text { biji }(\mathrm{g})\end{array}$ & $\begin{array}{c}\text { Produksi } \\
\text { terhadap tanaman } \\
\text { utama }(\%)\end{array}$ \\
\hline Kawali & - & 0.00 & 0.00 & 0.00 & 0.00 & 0.00 \\
Mandau & 115 & 6.98 & 2.99 & 11.87 & 0.18 & 48.94 \\
N/UP-118-3 & - & 0.00 & 0.00 & 0.00 & 0.00 & 0.00 \\
Numbu & 99 & 41.32 & 25.33 & 23.83 & 0.39 & 65.73 \\
UPCA & 90 & 17.79 & 7.42 & 16.24 & 0.39 & 48.94 \\
\hline
\end{tabular}


Korelasi Keragaan Tanaman Utama dengan Kemampuan Meratun dan Keragaan Tanaman Ratun

Semua genotipe yang ditanam menumbuhkan ratun. Namun hanya 3 dari 5 genotipe yang diuji menghasilkan produksi. Genotipe Kawali dan N/UP-118-3 hanya menumbuhkan ratun dengen persentase yang sangat kecil, sebesar 18.7 dan $11.3 \%$ dan sebagian besar tidak menghasilkan malai yang dapat diamati. Kemudian dilakukan analisis korelasi terhadap karakter tanaman utama 3 genotipe tersebut (Tabel 7). Karakter vegetatif tanaman utama berkorelasi dengan karakter reproduktif tanaman utama, karakter vegetatif ratun dan kemampuan meratun. Karakter vegetatif ratun berkorelasi dengan karakter reproduktif ratun. Karakter tanaman utama yang berkorelasi nyata dengan kemampuan meratun adalah tinggi tanaman, diameter batang, bobot basah brangkasan, bobot kering brangkasan, umur panen, dan indeks panen. Hasil penelitian ini sesuai dengan hasil penelitian ratun padi. Tanaman padi yang vigor sebagaimana ditunjukkan oleh tinggi tanaman dan diameter batang yang besar memiliki potensi ratun yang baik (Sinaga, 2015). Rata-rata jumlah mata tunas hidup mempunyai hubungan linear dengan bobot kering batang, bobot daun, panjang antar buku kedua dari permukaan tanah. Tumbuhnya tunas ratun berkorelasi dengan bobot kering batang, bobot kering, panjang antar buku kedua dari permukaan tanah, dan tinggi tanaman (Zhang et al., 2012).

Karakter tanaman utama yang berkorelasi nyata dengan keragaan tanaman ratun adalah tinggi tanaman utama, total klorofil daun, bobot basah brangkasan, bobot kering brangkasan, bobot malai, bobot biji per malai, bobor 1,000 biji, indeks panen, dan laju transpirasi. Karakter tanaman ratun yang berkorelasi nyata dengan karakter vegetatif dan produksi tanaman ratun yaitu tinggi tanaman, jumlah daun, diameter batang, dan bobot kering brangkasan.

Hasil sidik lintas pada Gambar 1 menunjukkan besarnya kontribusi karakter tanaman utama terhadap tinggi ratun. Model yang digunakan dapat menjelaskan keadaan sebesar $99.1 \%$, hal ini menunjukkan bahwa tinggi ratun dipengaruhi oleh karakter tanaman utama yang diuji. Bobot kering (1.72) dan bobot biji per malai (1.77) memberikan pengaruh langsung paling besar terhadap tinggi ratun. Gravois et al. (1991) menyatakan bahwa berdasarkan hasil sidik lintas diketahui bahwa volume batang mempunyai pengaruh langsung (0.99) terhadap bobot batang dan diameter batang mempunyai pengaruh langsung (0.83) terhadap volume batang.

Hasil sidik lintas pada Gambar 2 menunjukkan besarnya kontribusi karakter vegetatif ratun terhadap produksi ratun. Model yang digunakan dapat menjelaskan keadaan sebesar $82 \%$, hal ini menunjukkan bahwa produksi tanaman ratun dipengaruhi oleh vegetatif ratun. Karakter vegetatif ratun yang mempunyai pengaruh langsung paling besar terhadap bobot malai ratun adalah diameter batang (0.55) dan bobot kering ratun (0.80). Hal ini menunjukkan bahwa semakin tinggi nilai diameter batang dan bobot kering ratun, maka bobot malai ratun akan semakin tinggi. Samonte et al. (2006) menyatakan bahwa berdasarkan hasil sidik lintas, bobot batang pada saat heading dan panen mempunyai pengaruh langsung terhadap bobot biji tanaman padi.

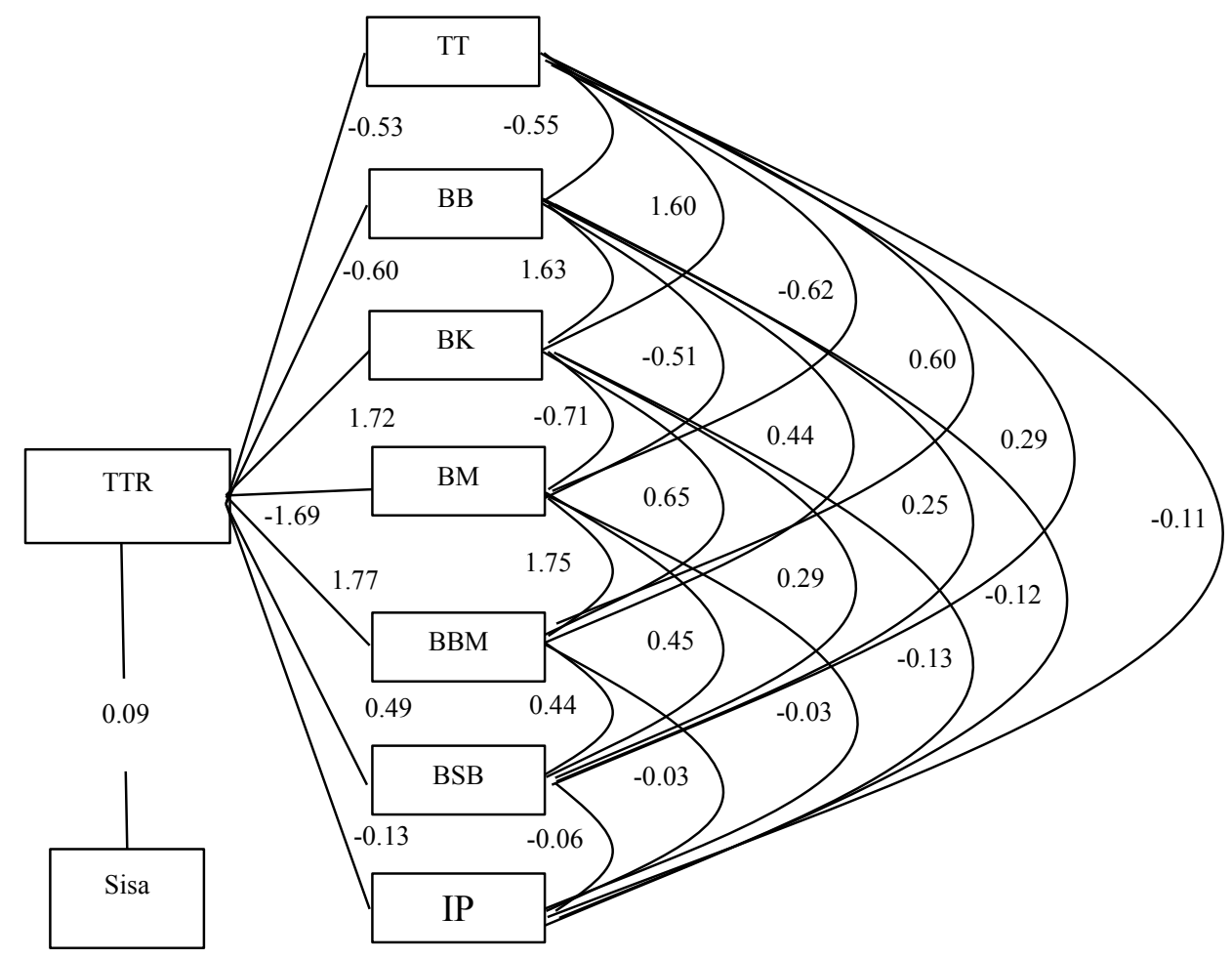

Gambar 1. Pengaruh langsung dan tidak langsung karakter tanaman utama terhadap tinggi ratun. TTR = tinggi ratun; TT = tinggi tanaman, $\mathrm{BB}=$ bobot basah; $\mathrm{BK}=$ bobot kering; $\mathrm{BM}=$ bobot malai; $\mathrm{BBM}=$ bobot biji per malai; $\mathrm{BSB}=$ bobot seribu biji; $\mathrm{IP}=$ indeks panen 


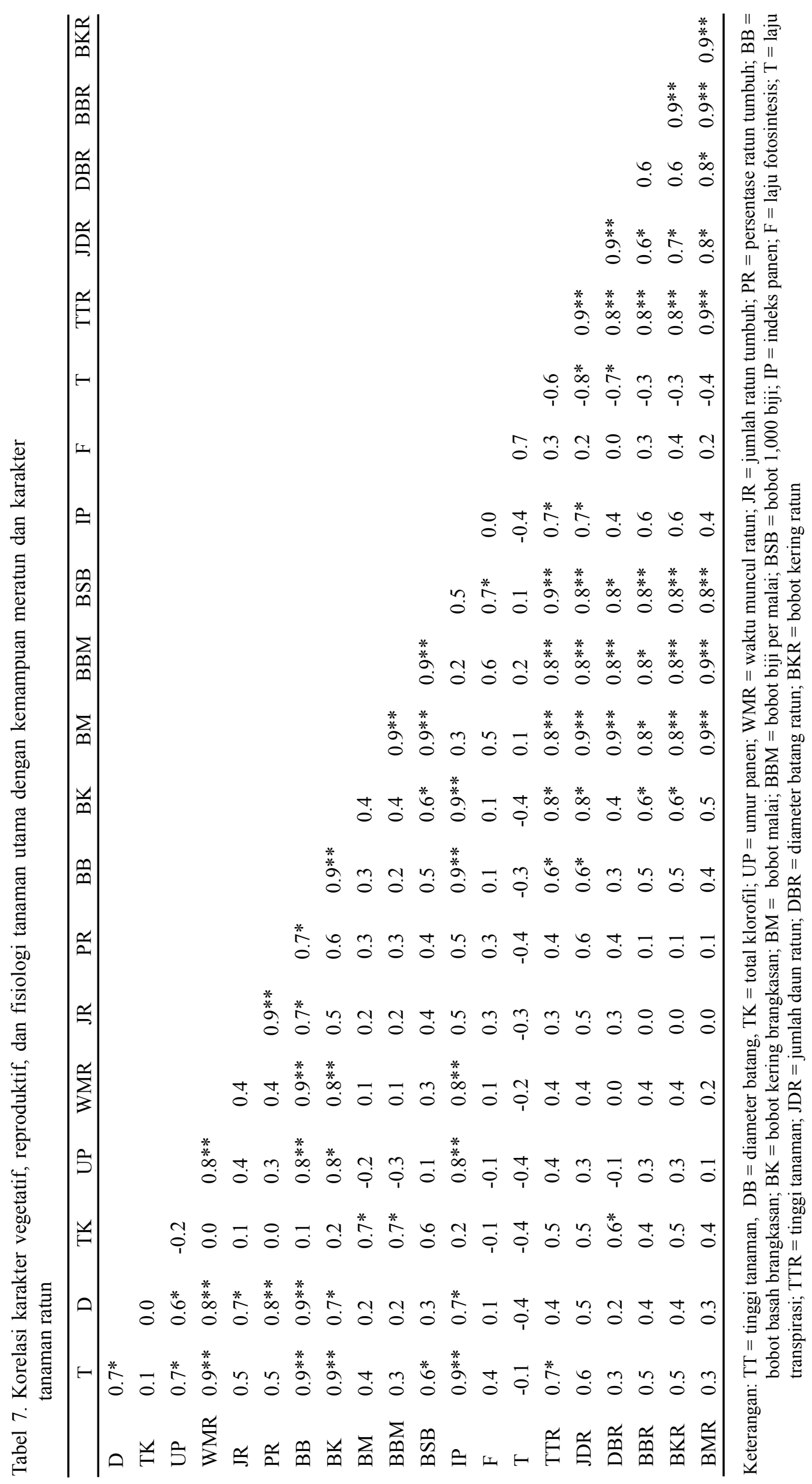




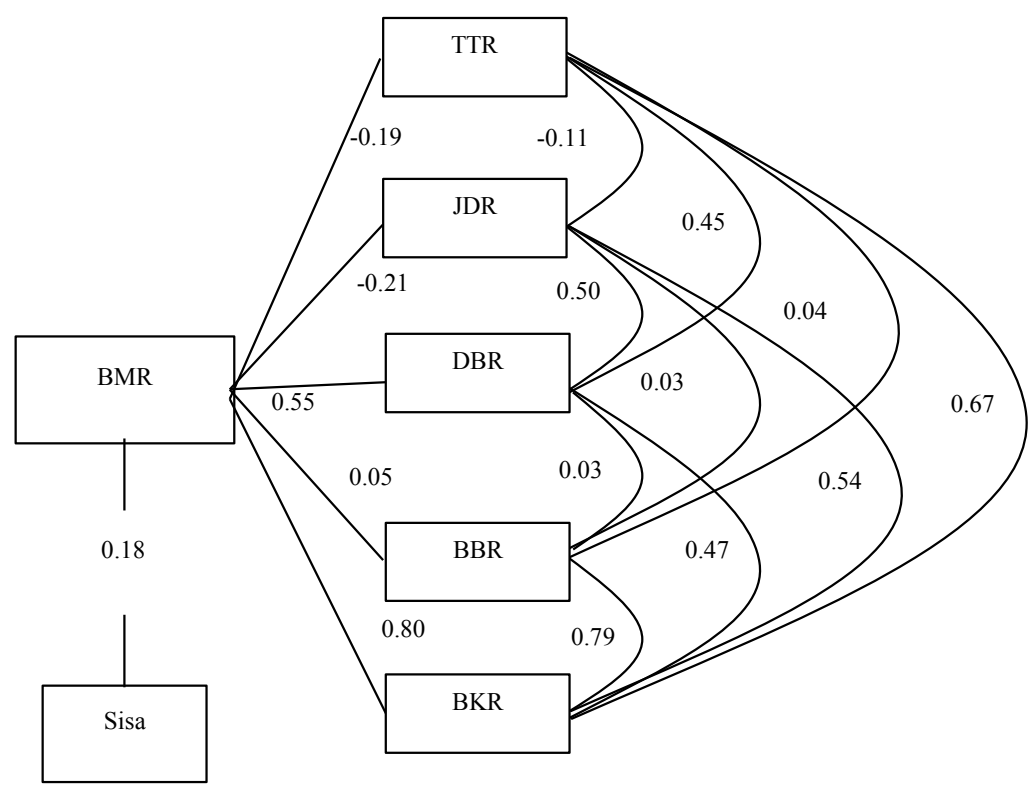

Gambar 2. Pengaruh langsung dan tidak langsung karakter vegetatif ratun sorgum terhadap bobot malai ratun. BMR = bobot malai ratun; $\mathrm{TTR}=$ tinggi tanaman ratun; JDR $=$ jumlah daun ratun; $\mathrm{DBR}=$ diameter batang ratun; $\mathrm{BBR}=$ bobot basah ratun; $\mathrm{BKR}=$ bobot kering ratun

\section{KESIMPULAN}

Genotipe berpengaruh nyata terhadap keragaan tanaman utama dan tanaman ratun. Produksi tanaman ratun sekitar $0-65.73 \%$ produksi tanaman utama. Berdasarkan hasil sidik lintas, bobot kering dan bobot biji per malai tanaman utama mempunyai pengaruh langsung paling besar terhadap tinggi ratun. Diameter batang dan bobot kering ratun mempunyai pengaruh langsung paling besar terhadap hasil ratun.

\section{UCAPAN TERIMA KASIH}

Terimakasih disampaikan kepada Direktorat Jenderal PendidikanTinggi, KementerianPendidikandanKebudayaan RI yang telah mendanai penelitian ini melalui International Research Collaboration and Scientific Publication dengan judul Sorghum Breeding Program for Improvement of Quality and Yield Potential pada tahun 2014.

\section{DAFTAR PUSTAKA}

Akhgari, H., S.A.N. Niyaki, S.M. Sadeghi. 2013. Effects of planting methods on yield and yield components of ratoon and main plant of rice (Oryza sativa (L.)) in Rasht, Iran. Indian J. Fundamental Appl. Life Sci. 3:150-157.

Amaducci, S., M. Colauzzi, F. Battini, Fracasso, A. Perego. 2016. Effect of irrigation and nitrogen fertilization on the production of biogas from maize and sorghum in water limited environtment. Europ. J. Agron. 76:5456.
Balasubramanian, R., K. Balakrishnan, S. Manoharan. 1992. Influence of stubble thickness, carbohydrate content and leaf senescence on ratoon rice. J. Agronomy Crop Sci. 168:10-12.

[BPS] Badan Pusat Statistik. 2013. Proyeksi Penduduk Indonesia. Badan Pusat Statistik, Jakarta.

Badan Pusat Statistik. 2015. Penduduk Indonesia Hasil Survei Penduduk Antar Sensus 2015. Badan Pusat Statistik, Jakarta.

Cosentino, S.L., M.G. Mantineo, Testa. 2012. Water and nitrogen balance of sweet sorghum (Sorghum bicolor moench (L.)) cv. Keller under semi-arid conditions. Industrial Crops Products 36:329-342.

Efendi, R., M. Aqil, M. Pabendon. 2013. Evaluasi genotipe sorgum manis (Sorghum bicolor (L.) Moench) produksi biomas dan daya ratun tinggi. Penelitian Pertanian Tanaman Pangan 32:116-125.

Gomathi, R., P.N.G. Rao, P. Rakkiyappan, B.P. Sundara. 2013. Physiological studies on ratoonability of sugarcane varieties under tropical Indian condition. AJPS. 4:274-281.

Gravois, K.A., S.B. Milligan, F.A Martin. 1991. Indirect selection for increased sucrose yield in early sugarcane testing stages. Field Crops Res. 26:67-73.

Harrell, D.L., J.A. Bond, S. Blanche. 2009. Evaluation of main crop stubble height on ratoon rice growth and development. Field Crops Research 114:396-403. 
Hassan, S.A., M.I. Mohammed, S.O. Yagoub. 2015. Breeeding for dual purpose attributes in sorghum: Effects of harvest option and genotype on fodder and grain yields. J. Plant Breed. Crop Sci. 7:101-106.

Liu, X., D. Feng, G.Yu, H. Zhao, L. Qiao, Y. Li, X. Fan, M. Liu, Q. Zhang. 2016. Effect of different sowing dates in South Henan's rice growing areas on the growth and yield of ratoon rice. Asian Agric. Res. 8:43-47.

Liu, K., J. Qin, Y. Zhao. 2012. Physiological traits, yield and nitrogen translocation of ratoon rice in response to different cultivations and planting periods. Afr. J. Agric. Res. 7:2539-2545.

Liu, K., Y.Z. Li, H.W. Hu. 2015. Predicting ratoon rice growth rhythm based on NDVI at key growth stages of main rice. Chilean J. Agric. Res. 75:410-417.

Mekbib, F. 2009. Farmers breeding of sorghum in the centre of diversity, Ethiopia: socio-ecotype differentiation, varietal mixture and selection efficiency. Maydica 54:25-37.

Nakano, H., S. Morita. 2007. Effects of twice harvesting in total dry matter yield of rice. Field Crops Res. 101:269-275.

Puspitasari, G., D. Kastono, S. Waluyo. 2012. Pertumbuhan dan hasil sorgum manis (Sorghum bicolor (L.) Moench) tanam baru dan ratoon pada jarak tanam berbeda. Vegetalika 1:18-29.

Saberi, A.R., H.S. Aishah. 2014. Physiological effects on regrowth of forage sorghums ratoon crop under varying salinity and irrigation frequency. British $\mathrm{J}$. Appl. Sci. Technol. 4:2277-2289.

Samonte, S.O.P.B., L.T. Wilson, R.E. Tabien. 2006. Maximum node production rate and main culm node number contributions to yield and yield-related traits in rice. Field Crops Research 96:313-319.

Sanni, K.A., D.K. Ojo, M.A. Adebisi, E.A. Somado, O.J. Ariyo, M. Sie, I. Akintayo, D.D. Tia, S.A. Ogunbayo, B. Cissè, M. Sikirou, M.A. Adekoya. 2009. Ratooning potential of interspecific NERICA rice varieties (Oryza glaberrima x Oryza sativa). Int. J. Bot. 5:112115.
Shah, S.M.A., H.U. Rahaman, Z. Iqbal, F.M. Abbasi, Durrishahwar, A. Ali, M.Y. Khan, D. Jan. 2008. Genotypic evaluation of sugarcane genotypes for ratooning ability. Sarhad.J.Agric. 24:613-618.

Sims, D.A., Gamon JA. 2002. Relationship between leaf pigment content and spectral reflectance across a wide range of species, leaf structures and developmental stages. Remote Sensing Environ. 81:337-354.

Sinaga, P.H. 2015. Analisis genetik potensi ratun genotipe padi (Oryza sativa (L.)) spesifik lahan pasang surut. Disertasi. Sekolah Pascasarjana. Institut Pertanian Bogor. Bogor.

Sinaga, P.H., Trikoesoemaningtyas, D. Sopandie, H. Aswidinnoor. 2015. Daya hasil dan stabilitas ratun galur padi pada lahan pasang surut. Penelitian Pertanian Tanaman Pangan 34:97-104.

Susilawati, B.S. Purwoko, H. Aswidinnoor, E. Santosa. 2012. Tingkat produksi ratun berdasarkan tinggi pemotongan batang padi sawah saat panen. J. Agron. Indonesia 40:1-7.

Viator, R.P., C.D. Dalley, R.M. Johnson, E.P. Richard. 2010. Early harvest affects sugarcane ratooning ability in Louisiana. Sugar Cane Internat. 28:123-127.

Wilson, K.S.L. 2011. Sorghum ratooning as an approach to manage covered kernel smut and the stem borer Chilo partellus. Disertasi. University of Greenwich. London.

Xiong, D., T. Yu, X. Ling, S. Fahad, S. Peng, Y. Li, J. Huang. 2014. Sufficient leaf transpiration and nonstructural carbohydrates are beneficial for high-temperature tolerance in three rice (Oryza sativa) cultivars and two nitrogen treatments. Funct. Plant Biol. 42:347356.

Yoshida, S., D.A. Forno, J.H. Cock, K.A. Gomez. 1976. Laboratory Manual for Physiological of Rice. The Rice Research Institute, Manila, Filipina.

Zhang L., H. Xiong, F. Xu, Y. Zhu, X. Guo, X. Zhou, M. Liu. 2012. Relationship between living rate of bud ang emergence rate of ratoon rice and characteristics of the first cropping mid-season hybrid rice. Agric. Sci. Technol. 13:1873-1876. 